\title{
Data report: early Late Cretaceous radiolarians from IODP Site U1520 (Expedition 375, Hikurangi subduction margin) ${ }^{1}$
}

\section{Contents}

1 Abstract

1 Introduction

1 Methods and materials

1 Results

2 Acknowledgments

2 References

4 Appendix

Christopher J. Hollis ${ }^{2}$

Keywords: International Ocean Discovery Program; IODP; JOIDES Resolution; Expedition 375; Hikurangi Subduction Margin Coring, Logging, and Observatories; Site U1520; radiolarians; Cretaceous, Cenomanian

\begin{abstract}
Poorly preserved radiolarians of early Late Cretaceous age have been recovered from International Ocean Discovery Program (IODP) Hole U1520C, which was drilled as part of IODP Expedition 375 (Hikurangi Subduction Margin Coring, Logging, and Observatories). Seven radiolarian-rich samples from Cores 375-U1520C$42 \mathrm{R}$ and 43R (1027.8-1037.5 meters below seafloor) contain a relatively uniform assemblage that includes species indicative of a middle Cenomanian age ( $97 \mathrm{Ma})$.
\end{abstract}

\section{Introduction}

During International Ocean Discovery Program (IODP) Expedition 375, shipboard analysis of cores from Site U1520 identified black siltstone intervals rich in organic matter in a unit of mixed volcaniclastic and terrigenous lithologies (Barnes et al., 2019). Preliminary biostratigraphic analysis of these sediments indicated a mid-Cretaceous age (Albian to Turonian). This suggested that the organic-rich interval might correspond to Oceanic Anoxic Event 2 (OAE2), which coincides with the Cenomanian/Turonian boundary (Jenkyns, 2010). Because radiolarians were noted during shipboard analysis, this study was undertaken to determine if radiolarian biostratigraphy could be used to refine the age control of the sediments and confirm the correlation with OAE2. Radiolarian biostratigraphy is relatively well resolved in the mid-Cretaceous following extensive studies of onshore sections in Europe, Japan, and North America and offshore studies in the low-latitude Pacific, Indian, and Atlantic Oceans (Sanfilippo and Riedel, 1985; O’Dogherty, 1994). However, there have been very few studies of radiolarian assemblages of this age from the southwest Pacific region (e.g., George, 1993).

\section{Methods and materials}

Radiolarian samples were processed in the Earth Science Laboratory at GNS Science. The samples were $\sim 5 \mathrm{~cm}^{3}$ splits of quarterround wedges that were selected for foraminiferal and nannofossil study. Samples were dried and crushed into $5 \mathrm{~mm}$ chips, leached in a solution of $10 \%$ hydrochloric acid until reaction ceased, immersed in a solution of $10 \%$ hydrogen peroxide and dilute Calgon, heated on a hot plate for $2 \mathrm{~h}$, and sieved through a $63 \mu \mathrm{m}$ screen. The fine fraction was not retained. Three highly siliceous samples did not break down with this treatment and therefore were leached in 5\% hydrofluoric acid for $1 \mathrm{~h}$, followed by decanting the spent acid, wet-sieving, and cleaning with the hydrogen peroxide and Calgon solution. The $>63 \mu \mathrm{m}$ fraction (i.e., residue) was dried in an oven at $60^{\circ} \mathrm{C}$. The dry residue for each radiolarian-bearing sample was mounted on two glass slides using Norland mounting medium. Radiolarians were identified and photographed using a Leitz Ortholux transmitted-light microscope fitted with an Opticom digital camera. Age assignments are based mainly on the unitary associations (UA) identified by O'Dogherty (1994) and, to a lesser extent, the zonal schemes established by Pessagno (1976), Taketani (1982) and Foreman (1975, as revised by Sanfilippo and Riedel, 1985). Unless noted otherwise, depths cited in the text are the midpoint within the sampled interval expressed as meters below seafloor (mbsf) (equivalent to core depth below seafloor, Method B [CSF-B]).

\section{Results}

Of the 19 samples processed from Cores 375-U1520C-41R through 43R, the uppermost two samples and lowermost two samples were barren of radiolarians (Table T1). Radiolarians were abun-

\footnotetext{
${ }^{1}$ Hollis, C.J., 2021. Data report: early Late Cretaceous radiolarians from IODP Site U1520 (Expedition 375, Hikurangi subduction margin). In Wallace, L.M., Saffer, D.M., Barnes, P.M., Pecher, I.A., Petronotis, K.E., LeVay, L.J., and the Expedition 372/375 Scientists, Hikurangi Subduction Margin Coring, Logging, and Observatories. Proceedings of the International Ocean Discovery Program, 372B/375: College Station, TX (International Ocean Discovery Program). https://doi.org/10.14379/iodp.proc.372B375.208.2021

2 GNS Science, New Zealand. C.Hollis@gns.cri.nz

MS 372B375-208: Received 8 October 2020 • Accepted 21 June 2021 • Published 17 December 2021

This work is distributed under the Creative Commons Attribution 4.0 International (CC BY 4.0) license. (cc) BY
} 
Table T1. Samples processed for radiolarians, Hole U1520C. Download table in CSV format.

Table T2. Cretaceous radiolarians, Hole U1520C. Download table in CSV format.

dant to rare and of moderately poor to very poor preservation over a $20 \mathrm{~m}$ interval from 1017.7 to $1037.53 \mathrm{mbsf}$ (Samples 42R-2, 49-54 $\mathrm{cm}$, to $43 \mathrm{R}-2,114-118 \mathrm{~cm}$ ). In the lower $10 \mathrm{~m}$ of this interval (1027.78-1037.53 mbsf), seven samples contain radiolarians of sufficient abundance and preservation for biostratigraphic study (Table T2). However, preservation is consistently poor, and taxonomic identification is hampered by the tests being recrystallized, infilled, and/or incomplete.

The radiolarian assemblages in this interval are similar to middle Cretaceous assemblages described from California (Pessagno, 1976, 1977), central Pacific Ocean (Schaaf, 1981), Hokkaido (Taketani, 1982), and central Tethyan localities in Italy and Spain (O'Dogherty, 1994). The radiolarian assemblages include a relatively uniform group of index species that indicate a middle Cenomanian age ( $97 \mathrm{Ma})$ (UA17-UA18 of O'Dogherty, 1994). The primary index species are Crucella messinae (middle to late Cenomanian), Theocapsomma fossilis (Aptian to middle Cenomanian), Theocapsomma rara (Albian to middle Cenomanian), Obesacapsula somphedia (early to middle Cenomanian), and Orbiculiforma cachensis (early Cenomanian). More information on the age ranges of these and other species encountered in this study are provided in the Appendix. The absence of Turonian index species such as Alievium superbum (Squinabol), Dictyomitra undata (Squinabol), and Crucella cachensis Pessagno provides further support for a Cenomanian age.

Little is known of the paleobiogeography of Cenomanian radiolarians. The assemblage described here has several species in common with several low- to mid-latitude regions, suggesting that these species are cosmopolitan. Some genera commonly reported from low-latitude and Northern Hemisphere assemblages (e.g., Pessagno, 1976; Taketani, 1982; O’Dogherty, 1994) such as Acaeniotyle, Pseudodictyomitra, and Thanarla are absent from this assemblage, whereas some of the species differ slightly from their Northern Hemisphere relatives. This suggests that the assemblage may represent a distinct southern mid-latitude biogeographic zone. This topic warrants further study.

\section{Acknowledgments}

This research used samples and/or data provided by the International Ocean Discovery Program (IODP). The shipboard science party of IODP Expedition 375 are thanked for their invitation to participate in this research and IODP is acknowledged for samples and data. Adam Woodhouse (University of Leeds) and Claire Shepherd (GNS Science) provided the sample splits used in this study. The samples were processed by Sonja Bermudez and Mus Hertoghs (GNS Science). The study is funded by New Zealand's Ministry of Business, Innovation, and Employment (MBIE) Endeavour Hikurangi Subduction Margin Programme. Chris Clowes, Martin Crundwell (GNS Science), and an anonymous reviewer are thanked for their careful reviews.

\section{References}

Barnes, P.M., Wallace, L.M., Saffer, D.M., Pecher, I.A., Petronotis, K.E., LeVay, L.J., Bell, R.E., Crundwell, M.P., Engelmann de Oliveira, C.H., Fagereng, A., Fulton, P.M., Greve, A., Harris, R.N., Hashimoto, Y., Hüpers, A., Ikari, M.J., Ito, Y., Kitajima, H., Kutterolf, S., Lee, H., Xuesen, L., Min, L., Malie, P.R., Meneghini, F., Morgan, J.K., Noda, A., Rabinowitz, H.S., Savage, H.M., Shepherd, C.L., Shreedharan, S., Solomon, E.A., Underwood, M.B., Maomao, W., Woodhouse, A.D., Bourlange, S.M., Brunet, M.M.Y., Cardona, S., Clennell, M.B., Cook, A.E., Dugan, B., Elger, J., Gamboa, D., Georgiopoulou, A., Han, S., Heeschen, K.U., Gaowei, H., Kim, G.Y., Koge, H., Machado, K.S., McNamara, D.D., Moore, G.F., Mountjoy, J.J., Nole, M.A., Owari, S., Paganoni, M., Rose, P.S., Screaton, E.J., Shankar, U., Torres, M.E., and Xiujuan, W., 2019. Site U1520. In Wallace, L.M., Saffer, D.M., Barnes, P.M., Pecher, I.A., Petronotis, K.E., LeVay, L.J., and the Expedition 372/375 Scientists, Hikurangi Subduction Margin Coring, Logging, and Observatories. Proceedings of the International Ocean Discovery Program, 372B/375: College Station, TX (Proceedings of the International Ocean Discovery Program).

https://doi.org/10.14379/iodp.proc.372B375.105.2019

Campbell, A.S., and Clark, B.L., 1944. Radiolaria from Upper Cretaceous of middle California. Special Paper - Geological Society of America, 57. https://doi.org/10.1130/SPE57

Empson-Morin, K.M., 1981. Campanian radiolaria from DSDP Site 313, midPacific mountains. Micropaleontology, 27(3):249-292. https://doi.org/10.2307/1485238

Foreman, H.P., 1968. Upper Maestrichtian radiolaria of California. Special Papers in Palaeontology, 3. https://www.palass.org/publications/special-papers-palaeontology/archive/3/article_pp1-82

Foreman, H.P., 1973. Radiolaria from DSDP Leg 20. In Heezen, B.C., MacGregor, I.D., et al., Initial Reports of the Deep Sea Drilling Project. 20: Washington, DC (US Government Printing Office), 249-305. https://doi.org/10.2973/dsdp.proc.20.113.1973

Foreman, H.P., 1975. Radiolaria from the North Pacific, Deep Sea Drilling Project, Leg 32. In Larson, R.L., Moberly, R., et al., Initial Reports of the Deep Sea Drilling Project. 32: Washington, DC (US Government Printing Office), 579-676. https://doi.org/10.2973/dsdp.proc.32.123.1975

Foreman, H.P., 1978. Cretaceous radiolaria in the eastern South Atlantic, Deep Sea Drilling Project, Leg 40. In Bolli, H.M., Ryan, W.B.F., et al., Initial Reports of the Deep Sea Drilling Project. 40: Washington, DC (US Government Printing Office), 839-843. https://doi.org/10.2973/dsdp.proc.40.122.1978

George, A.D., 1993. Radiolarians in offscraped seamount fragments, Aorangi Range, New Zealand. New Zealand Journal of Geology and Geophysics, 36(2):185-199. https://doi.org/10.1080/00288306.1993.9514567

Hok, T.S., 1927. Over de samenstelling en het onstaan van krijt- en mergelgesteenten van de Molukken. Yearbook of Mining in the Dutch East Indies, 55. http://resolver.tudelft.nl/uuid:3913a920-2448-4603-a567d71c14efd221

Hollis, C.J., 1997. Cretaceous-Paleocene radiolaria from eastern Marlborough, New Zealand. Institute of Geological \& Nuclear Sciences Monograph, 17.

Hollis, C.J., 2002. Biostratigraphy and paleoceanographic significance of Paleocene radiolarians from offshore eastern New Zealand. Marine Micropaleontology, 46(3-4):265-316. https://doi.org/10.1016/S0377-8398(02)00066-X

Hollis, C.J., Pascher, K.M., Sanfilippo, A., Nishimura, A., Kamikuri, S., and Shepherd, C.L., 2020. An Austral radiolarian biozonation for the Paleogene. Stratigraphy, 17(4):213-278.

Jenkyns, H.C., 2010. Geochemistry of oceanic anoxic events. Geochemistry, Geophysics, Geosystems, 11(3):Q03004.

https://doi.org/10.1029/2009GC002788 
O'Dogherty, L., 1994. Biochronology and Paleontology of Mid-Cretaceous Radiolarians from Northern Apennines (Italy) and Betic Cordillera (Spain). Mémoires de Géologie (Lausanne), 21.

Pessagno, E.A., Jr., 1971. Jurassic and Cretaceous Hagiastridae from the BlakeBahama Basin (Site 5A, JOIDES Leg I) and the Great Valley sequence, California Coast Ranges. Bulletin of American Paleontology, 60(264):583.

Pessagno, E.A., 1976. Radiolarian Zonation and Stratigraphy of the Upper Cretaceous Portion of the Great Valley Sequence, California Coast Ranges: New York (Micropaleontology Press).

Pessagno, E.A., 1977. Lower Cretaceous radiolarian biostratigraphy of the Great Valley sequence and Franciscan complex, California Coast Ranges. Special Publication - Cushman Foundation for Foraminiferal Research, 15.
Sanfilippo, A., and Riedel, W.R., 1985. Cretaceous radiolaria. In Bolli, H.M., Saunders, J.B., and Perch-Nielsen, K. (Eds.), Plankton stratigraphy: New York (Cambridge University Press), 573-630.

Schaaf, A., 1981. Late Early Cretaceous radiolaria from Deep Sea Drilling Project Leg 62. In Thiede, J., Valuer, T.L., et al., Initial Reports of the Deep Sea Drilling Project. 62: Washington, DC (US Government Printing Office), 419-470. https://doi.org/10.2973/dsdp.proc.62.112.1981

Squinabol, S., 1903. Le Radiolarie dei noduli selciosi nella Scaglia degli Euganei. Contributi a Rivista Italiana di Paleontologia, 9:105-151.

Squinabol, S., 1904. Radiolarie cretacee degli Euganei. Atti e Memorie della Reale Accademia di Scienze, Lettere ed Arti, 20:171-244.

Taketani, Y., 1982. Cretaceous radiolarian biostratigraphy of the Urakawa and Obira areas, Hokkaido. The Science Reports of the Tohoku University, 2nd Series. Geology, 52(1-2):1-75. 


\section{Appendix Taxonomic notes}

Brief notes are provided on the illustrated species (Plates P1, P2, P3, P4). These include remarks on the distinguishing taxonomic features of the species and comments on the established age range. Selected synonymy lists and references are provided to clarify the species concept applied here and the basis of age ranges.

\section{Amphipyndax stocki (Campbell and Clark)}

(Plate P3, figures 12, 13)

Amphipyndax stocki (Campbell and Clark), Foreman, 1968, p. 78, pl. 8, figs. 12a-12c; Hollis, 1997, p. 66, pl. 15, fig. 5-11.

Stichomitra stocki (Campbell and Clark), O'Dogherty, 1994, p. 147, pl. 18, figs. 9-15.

Remarks: Narrowly conical to bullet-shaped test of 5 or more segments, with or without constricted joints. Distinctive cephalis with internal partition may be a raised knob with a constricted neck or partly encased in the thorax. One specimen encountered in this study is uncertainly ascribed to $A$. stock $i$ because the pore frames in the upper 3-4 postthoracic segments bear short thorns ( $A$. aff. stocki; Plate P4, figures 1a, 1b).

Age range: Late Cenomanian (UA18-UA21; O'Dogherty, 1994) to late Paleocene (Zones RKA9-RPA6; Hollis, 1997, 2002).

\section{Archaeodictyomitra squinaboli Pessagno}

(Plate P4, figures 4a-6)

Archaeodictyomitra squinaboli Pessagno, 1976, p. 50, pl. 5, fig. 2-8.

Remarks: Narrowly conical to bullet-shaped test of 7-9 segments; 11 widely spaced costae in lateral view.

Age range: Albian to early Campanian (Pessagno, 1976).

\section{Crucella messinae Pessagno}

(Plate P1, figures 2, 3)

Crucella messinae Pessagno, 1971, p. 56, pl. 6, figs. 1-3; 1976, p. 32, pl, 1, fig. 4; 1977, p. 27, pl. 1, figs. 3, 4, 13; Taketani, 1982, p. 50, pl. 9, fig. 17.

Remarks: Distinguished from the Turonian species C. cachensis by lacking central depression (lacuna) and by rays bearing prominent triradiate spines (when complete). Both species develop patagium of the type evident in the specimens illustrated here.

Age range: Middle to late Cenomanian (Pessagno, 1976).

\section{Cryptamphorella conara (Foreman)}

(Plate P1, figures 7a, 7b)

Hemicryptocapsa conara Foreman, 1968, p. 35, pl. 4, figs. 11a, 11 b. Cryptamphorella conara (Foreman), Sanfilippo and Riedel, 1985, p.

613, figs. 12.1a-12.1c.

Remarks: Three-segmented test, with small spherical cephalis, short and narrow thorax, which is partly encased in the abdomen; large spheroidal abdomen without a basal aperture.

Age range: Albian to Maastrichtian.

\section{Dictyomitra multicostata Zittel (Plate P4, figure 2)}

Dictyomitra multicostata Zittel, p. 81, pl. 2, figs. 2-4; O’Dogherty, 1994, p. 82, pl. 4, figs. 17-19; Hollis, 1997, p. 69, pl. 16, figs. 610.

Remarks: Multisegmented, narrowly conical test with segments increasing regularly in width until the last $2-3$ segments, which are of uniform width. Costae are well developed and lack the dimples or waviness that typify species such as Dictyomitra andersoni and Dictyomitra urakawaensis; distinct constrictions at joints resulting in a weakly crenulated outline.

Age range: According to O'Dogherty (1994), this species first appears in the Turonian (from UA21), possibly evolving from Dictyomitra formosa. However, very similar morphotypes occur from at least the Aptian and cannot easily be differentiated from this species when preservation is moderate to poor. Hollis (1997) found the species ranged into the late Paleocene in the southwest Pacific.

\section{Dictyomitra urakawaensis Taketani}

(Plate P4, figure 3)

Dictyomitra urakawaensis Taketani, 1982, p. 59, pl. 4, figs. 8a, 8b; pl. 11, fig. 16.

Remarks: Multisegmented, narrowly conical test with segments increasing regularly in width until the last $2-3$ segments, which are of uniform width. Costae are well developed; relict pores in longitudinal intercostal rows give costae a dimpled or wavy appearance as is also seen in $D$. andersoni; well-developed constrictions at joints resulting in a crenulated outline. Distinguished from $D$. andersoni by having segments that increase regularly in size.

Age range: Cenomanian-Turonian in Hokkaido (Taketani, 1982).

\section{Distylocapsa veneta (Squinabol)}

(Plate P3, figures 6-7b)

Eusyringium venetum Squinabol, 1904, p. 235, pl. 10, fig. 10.

Stichomitra foraminosa Taketani, 1982, p. 55, pl. 3, figs. 5a, 5b, 6a, 6b).

Distylocapsa veneta (Squinabol), O’Dogherty, 1994, p. 186, p. 28, figs. 10-15.

Remarks: Spindle-shaped test of 4-5 segments; small cephalis with short apical horn; subsequent segments increase gradually in width; last segment hemispherical, terminates in a short antapical spine; test wall thick, densely perforate.

Age range: Late Albian to late Cenomanian in the Tethys (UA13-UA18; O'Dogherty, 1994), possibly ranging into Coniacian in Hokkaido (Taketani, 1982).

\section{Dorypyle cf. elliptica Squinabol}

(Plate P1, figures 6a, 6b)

cf. Dorypyle elliptica Squinabol, O’Dogherty, 1994, p. 206, pl. 33, figs. 8-15.

Remarks: Differs slightly from the specimens illustrated by O'Dogherty (1994) by the upper thorax becoming weakly conical around a small apical spine; cephalis fully encased in thorax.

Age range: $D$. elliptica is restricted to the middle to late Albian (UA11-UA13; O’Dogherty, 1994).

\section{Hiscocapsa cf. asseni (Tan) \\ (Plate P1, figures 14a, 14b)}

cf. Tricolocapsa spinosa Tan Sin Hok, 1927, p. 49, pl. 9, fig. 62. cf. Cyrtocapsa asseni Tan Sin Hok, 1927, p. 67, pl. 14, figs. 118, 119. cf. Sethocapsa simplex Taketani, 1982, p. 63, pl. 5, figs. 8a-8c; pl. 13, fig. 1.

cf. Hiscocapsa asseni (Tan), O’Dogherty, 1994, p. 200, pl. 31, figs. 713.

Remarks: Generic assignment follows the definition of O'Dogherty (1994; p. 197). Test of 3-4 segments with the first 2-3 seg- 
ments small and conical and the final segment globose and open at the base. Cephalis small and spheroidal without an apical spine. The illustrated specimen appears to have only 3 segments as in Tricolocapsa spinosa. However, in other respects it closely resembles the 4-segmented species listed above and synonymized as $H$. asseni by O’Dogherty (1994).

Age range: According to O'Dogherty (1994), H. asseni is restricted to the Early Cretaceous (Barremian-early Albian, UA1UA10), However, Taketani (1982) described S. simplex from the Cenomanian-Turonian Middle Yezo Group of Hokkaido. The latter range is more in line with other species encountered in this study.

\section{Lithocampe wharanui Hollis}

(Plate P3, figures 4, 5)

Stichomitra manifesta Foreman, Taketani, 1982, p. 55, pl. 3, figs. 8a, 8b; pl. 11, figs. 7, 8 (non Foreman, 1978). Lithocampe wharanui Hollis, 1997, p. 76, pl. 18, figs. 8-10. Lithocampe aff. subligata Stöhr, Hollis, 1997, p. 77, pl. 18, figs. 11, 12.

Remarks: Distinctive test of 5 or more inflated segments with well-developed constrictions at joints; a dimpled spherical cephalis without an apical spine; large hemispherical thorax; abdomen and subsequent 2-4 segments increase regularly in size; final segment is narrower and tapers to a short tube. This species differs from $S$. manifesta Foreman by having inflated postthoracic segments that increase in size.

Age range: This appears to be a long-ranging Late CretaceousPaleocene species with a latest Turonian-early Campanian range in Hokkaido, Japan (Taketani, 1982) and a Maastrichtian-middle Paleocene in the southwest Pacific (Hollis, 1997).

\section{Mita gracilis (Squinabol) \\ (Plate P4, figures 7a, 7b, ?8)}

Sethoconus gracilis Squinabol, 1903, p. 131, pl. 10, fig. 13.

Mita gracilis (Squinabol), Taketani, 1982, p. 60, pl. 5, figs. 2a, 2b; pl. 12, fig. 3.

Dictyomitra gracilis (Squinabol), O’Dogherty, 1994, p. 73, pl. 1, figs. 12-25.

Remarks: Distinguished from Mita regina by a sharply pointed cephalis, usually bearing a short apical spine, and a narrowly conical upper test with a globose lower test. Specimens in which the lower part of the test is missing are uncertainly referred to $M$. gracilis (Plate P4, figure 8).

Age range: Early Albian to middle Cenomanian (UA10-UA17; O’Dogherty, 1994).

\section{Obesacapsula somphedia (Foreman)} (Plate P3, figures 1a-3b)

Dictyomitra somphedia Foreman, 1973, p. 264, pl. 14, fig. 18; Foreman, 1975, p. 614, pl. 7, figs. 11-13.

Obesacapsula somphedia (Foreman), Schaaf, 1981, p. 435, pl. 4, figs. 6-9; pl. 20, figs. 1a-2; Sanfilippo and Riedel, 1985, p. 609, figs. $10.4 \mathrm{a}-10.4 \mathrm{c}$.

non Xitus spinosus (Squinabol), O’Dogherty, 1994, p. 129, pl. 12,

figs. 1-13.

Remarks: Large test, tending to be gourd-shaped; cephalis partly encased in thorax; small thorax of similar length to thorax; postthoracic segments either subcylindrical, ellipsoidal, or gourd-shaped with segmentation variable; distal part of test spongy, tapering with a constricted aperture. The postthoracic test in specimens encountered in this study tends to comprise 2-3 lobate segments increas- ing in size distally, with the cephalothorax encased in the first segment and the final segment tapering to a constricted aperture or antapical spine. A specimen in which the postabdominal segment is cylindrical and narrower than the abdomen (Plate P3, figures 3a, 3b) is provisionally included here. O'Dogherty (1994) synonymizes this species with $X$. spinosus, but the rationale for this is not explained and the specimens illustrated bear little resemblance to $O$. somphedia. See discussion under X. spinosus.

Age range: Early to middle Cenomanian (Sanfilippo and Riedel, 1985).

\section{Orbiculiforma cachensis Pessagno}

(Plate P1, figure 5)

Orbiculiforma cachensis Pessagno, 1976, p. 34, pl. 1, figs. 13, 15.

Remarks: Distinguished by a polygonal outline and short triradiate spines at the polygon vertices. O'Dogherty (1994) treats this species as a junior synonym of Dactyliosphaera acutispina (Squinabol). The species may be closely related, but the peripheral spines are much longer in D. acutispina, almost as long as the diameter of the central disc. For this reason, the species are not synonymized here.

Age range: O. cachensis is restricted to the early Cenomanian in California (Pessagno, 1976). D. acutispina has a longer range that extends from middle Albian to earliest Cenomanian (UA11-UA15; O’Dogherty, 1994).

\section{Orbiculiforma cf. renillaeformis (Campbell and Clark)} (Plate P1, figure 4)

cf. Spongodiscus renillaeformis Campbell and Clark, 1944, p. 18, pl. 6, figs. 5, 6, 8, 10. cf. Orbiculiforma renillaeformis (Campbell and Clark), Pessagno, 1976, p. 36, pl. 11, fig. 11; Hollis, 1997, p. 50, pl. 9, figs. 1-7.

Remarks: Differs from O. renillaeformis s.s. by having short spines distributed evenly around the periphery rather than restricted to the marginal notch. Similar to the much larger species Orbiculiforma maxima (Pessagno).

Age range: O. renillaeformis ranges from the late Campanian to Paleocene (Hollis, 1997).

\section{Solenotryma cf. dacryodes Foreman}

(Plate P1, figure 13)

cf. Solenotryma dacryodes Foreman, 1968, p. 33, pl. 4, fig. 8; Sanfilippo and Riedel, 1985, p. 622, fig. 14.5 (s.l.).

?Solenotryma cf. dacryodes Foreman, 1968, p. 33, pl. 4, fig. 7.

Remarks: The species encountered in this study has 3 segments with a large and spheroidal abdomen bearing an antapical spine. Its flask-shaped test is reminiscent of Eusyringium woodsidensis Hollis but its finely perforate and thin-walled test suggests a closer relationship to $S$. dacryodes.

Age range: $S$. dacryodes s.l. ranges from the Albian to the Campanian (Sanfilippo and Riedel, 1985).

\section{Stichomitra carnegiense (Campbell and Clark) \\ (Plate P3, figures 9a-10b)}

Eucyrtidium carnegiense Campbell and Clark, 1944, p. 42, pl. 8, figs. $36,37$.

Stichomitra warzigita (Empson-Morin), Taketani, 1982, p. 56, pl. 3, figs. 10a, 10b; pl. 11, fig. 9 (non Empson-Morin, 1981).

Stichomitra carnegiense (Campbell and Clark), Hollis, 1997, p. 78, pl. 19, figs. 7-12. 
Age range: Cenomanian to middle Paleocene (Taketani, 1982; Hollis, 1997).

\section{Stichomitra communis Squinabol}

(Plate P3, figures 8a, 8b)

Stichomitra communis Squinabol, 1903, p. 141, pl. 8, fig. 40; Taketani, p. 54, pl. 3, fig. 9; pl. 11, fig. 5; O’Dogherty, 1994, pl. 17, figs. 6-16.

Remarks: See the extensive synonymy list in O'Dogherty (1994).

Age range: Aptian to Coniacian (Taketani, 1982; O'Dogherty, 1994 [UA5-UA21]).

\section{Theocapsomma erdnussa (Empson-Morin) \\ (Plate P1, figures 10a-11)}

Novodiacanthocapsa erdnussa Empson-Morin, 1981, p. 270, pl. 10, figs. 1a-1c.

Theocapsomma erdnussa (Empson-Morin), Hollis, 1997, p. 65, pl. 14 figs. 14-21 (?22, 23).

Remarks: Theocapsomma is considered to be the senior synonym of Diacanthocapsa and Novodiacanthocapsa (Hollis, 1997).

Age range: This species has not been previously recorded from sediments older than late Campanian. It ranges into the middle $\mathrm{Pa}$ leocene in the southwest Pacific (Zone RPA5; Hollis, 1997; Hollis et al., 2020).

\section{Theocapsomma aff. euganea (Squinabol)}

(Plate P1, figures 15a-17)

Diacanthocapsa euganea Squinabol, 1903, p. 133, pl. 8, fig. 26; Taketani, 1982, p. 68, pl. 8, figs. 2a-3b; pl. 12, fig. 15; O’Dogherty, 1994, p. 218, pl. 36, figs. 19-21.

Remarks: Three segments with cephalis mainly encased in hemispherical thorax; conical apical spine; abdomen inflated distally, tapering to a constricted aperture or enclosed with a small antapical spine. The specimens encountered in this study differ from T. euganea by having a cephalis that is not completely encased in the thorax and tends to be surrounded by a circlet of small upwarddirected thorns in addition to bearing a sturdy apical spine.

Age range: T. euganea is restricted to the middle to late Cenomanian in the Tethys (UA17-UA19; O'Dogherty, 1994), perhaps ranging into the late Turonian in Japan (Taketani, 1982).

\section{Theocapsomma fossilis (Squinabol)}

(Plate P1, figures 8-9b)

Dicolocapsa fossilis Squinabol, 1904, p. 218, pl. 7, fig. 19 (?fig. 13); O’Dogherty, 1994, p. 217, pl. 36, figs. 8-11.

Remarks: Three segments with cephalis mainly encased in thorax; thorax hemispherical to campanulate; abdomen larger than thorax, distinctly trilobate in cross section, constricted basally forming a small aperture. Pores on thorax are arranged quincuncially with hexagonal pore frames. Pores on abdomen are smaller and more numerous and lack pore frames. The specimens encountered in this study range between those with typical pore arrangements (Plate P1, figure 8) and those in which the abdominal pores are similar in size or larger than those on the abdomen (Plate P1, figures 9a, 9b).

Age range: Late Aptian to middle Cenomanian (UA9-UA17; O’Dogherty, 1994).

\section{Theocapsomma rara (Squinabol)}

(Plate P2, figures 9a-10b)

Dicolocapsa rara Squinabol, 1904, p. 218, pl. 7, fig. 17; O’Dogherty, 1994 , p. 218, pl. 36, figs. $12-18$.

Remarks: Spindle shaped test of three segments; cephalis encased in thorax but bears a strong three-bladed apical spine. Thorax may also be partly encased in abdomen; abdomen terminates in a tapering conical tube; abdomen tends to be trilobate in cross section.

Age range: Late Albian to middle Cenomanian (UA13-UA17; O’Dogherty, 1994).

\section{Theocapsomma? cf. matsumotoi (Taketani) \\ (Plate P2, figures 1a-8)}

cf. Eucyrtidium? matsumotoi Taketani, 1982, p. 57, pl. 4, figs. 1a-3b; pl. 11, figs. 11, 12. non Diacanthocapsa matsumotoi (Taketani), O'Dogherty, 1994, p.

219, pl. 36, figs. 22-24.

Remarks: Four segments with cephalis partly encased in hemispherical to trapezoidal thorax; prominent apical spine; abdomen inflated medially or slightly distally; fourth segment globose to inverted conical, terminates in a prominent antapical spine (e.g., Plate $\mathbf{P 2}$, figures $4 \mathrm{a}-5 \mathrm{~b}$ ) or short tube (Plate P2, figures $6 \mathrm{a}-8$ ). In the specimens illustrated by O'Dogherty, the cephalis is enclosed in the thorax and therefore the assignment to Theocapsomma (Diacanthocapsa sensu O'Dogherty, 1994) seems justified; they seem closely related to the type species of Diacanthocapsa, T. euganea (see above). However, the cephalis is only partly encased in the thorax in the species described and illustrated by Taketani and quite distinct from the specimens identified as T. euganea by Taketani. This explains Taketani's tentative placement of his species in Eucyrtidium. The specimens encountered in the present study are similar to Taketani's species in this respect and so tentative assignment to Eucyrtidium is retained. They differ from E.? matsumotoi by lacking a distinctly trilobed fourth segment. As with the species uncertainly ascribed to T. euganea here, the cephalis is sometimes surrounded by a circlet of small thorns.

Age range: Eucyrtidium? matsumotoi of Taketani (1982) ranges from the Coniacian to the Campanian in Hokkaido, whereas the species referred to D. matsumotoi by O'Dogherty (1994) is restricted to the late Cenomanian in the Tethys (UA18-UA19). The species encountered in this study may have evolved into E.? matsumotoi s.s., but it may not be closely related to the species reported by O’Dogherty (1994).

\section{Xitus spinosus (Squinabol) \\ (Plate P3, figure 11)}

Theocorys spinosa Squinabol, 1904, p. 222, pl. 8, fig. 9.

Xitus spinosus (Squinabol), O’Dogherty, 1994, p. 129, pl. 12, figs. 113 (in part).

Xitus takayanagii Taketani, 1982, p. 62, pl. 5, figs. 5a, 5b; pl. 12, fig. 14.

?Stichomitra asymbatos Foreman, 1968, p. 73, pl. 8, figs. 10a-10c. ?Stichomitra grandis (Campbell and Clark), Hollis, 1997, p. 78, pl.

19, figs. $1-4$.

non Dictyomitra somphedia Foreman, 1973, p. 264. pl. 14, fig. 18 non Obesacapsula somphedia (Foreman), Sanfilippo and Riedel,

1985 , p. 609 , figs. $10.4 \mathrm{a}-10.4 \mathrm{c}$. 
Remarks: Multisegmented test with thickened pore frames and spinose tubercles. O'Dogherty (1994) synonymized O. somphedia with this species, apparently based on the holotype illustrated by Foreman (1973; pl. 14, fig. 18). However, although this specimen resembles $X$. spinosus superficially, it is described as having a test in which the lower portion has a thickened spongy wall (hence the species name, which means spongy base). This is diagnostic of the
Spongocapsulidae (Pessagno, 1977) and is consistent with subsequent illustrations of the species that formed the basis for ascribing the species to the spongocapsulid genus Obesacapsula. For this reason, O. somphedia is not synonymized with $X$. spinosus here.

Age range: Early Albian to upper Cenomanian in the Tethys (UA10-UA18; O'Dogherty, 1994) although it appears to range into the Campanian in Hokkaido (Taketani, 1982). 
Plate P1. Selected radiolarians, Hole U1520C. Scale bars $=100 \mu \mathrm{m}$. Location of specimen on slide (A or B) is given by England Finder coordinates. 1. Archeospongoprunum sp. (42R-4, 36-39 cm) (A-E28/1). 2, 3. Crucella messinae (42R-4, 36-39 cm); (2) B-X49/0, (3) A-S61/2. 4. Orbiculiforma cf. renillaeformis (42R-4, 36-39 cm) (A-D62/0). 5. Orbiculiforma cachensis (42R-4, 36-39 cm) (A-H33/3). 6a, 6b. Dorypyle cf. elliptica (43R-1, 128-131 cm) (A-K44/3). 7a, 7b. Cryptamphorella conara (43R-1, 128-131 cm) (A-M29/1). 8-9b. Theocapsomma fossilis; (8) A-K51/0 (42R-4, 36-39 cm), (9a, 9b) A-E51/0 (43R-1, 128-131 cm). 10a-11. Theocapsomma erdnussa; (10a, 10b) A-J60/4 (43R-1, 128-131 cm), (11) B-T28/0 (43R-2, 114-118 cm). 12. Theocapsomma sp. (43R-1, 128-131 cm) (A-E58/0). 13. Solenotryma cf. dacryodes (43R-1, 128-131 cm) (A-X52/20). 14a, 14b. Hiscocapsa cf. asseni (43R-1, 128-131 cm) (A-Q59/2). 15a-17. Theocapsomma cf. euganea (43R-1, 128-131 cm); (15a, 15b) A-F54/3, (16a, 16b) A-J55/1, (17) A-F52/3.
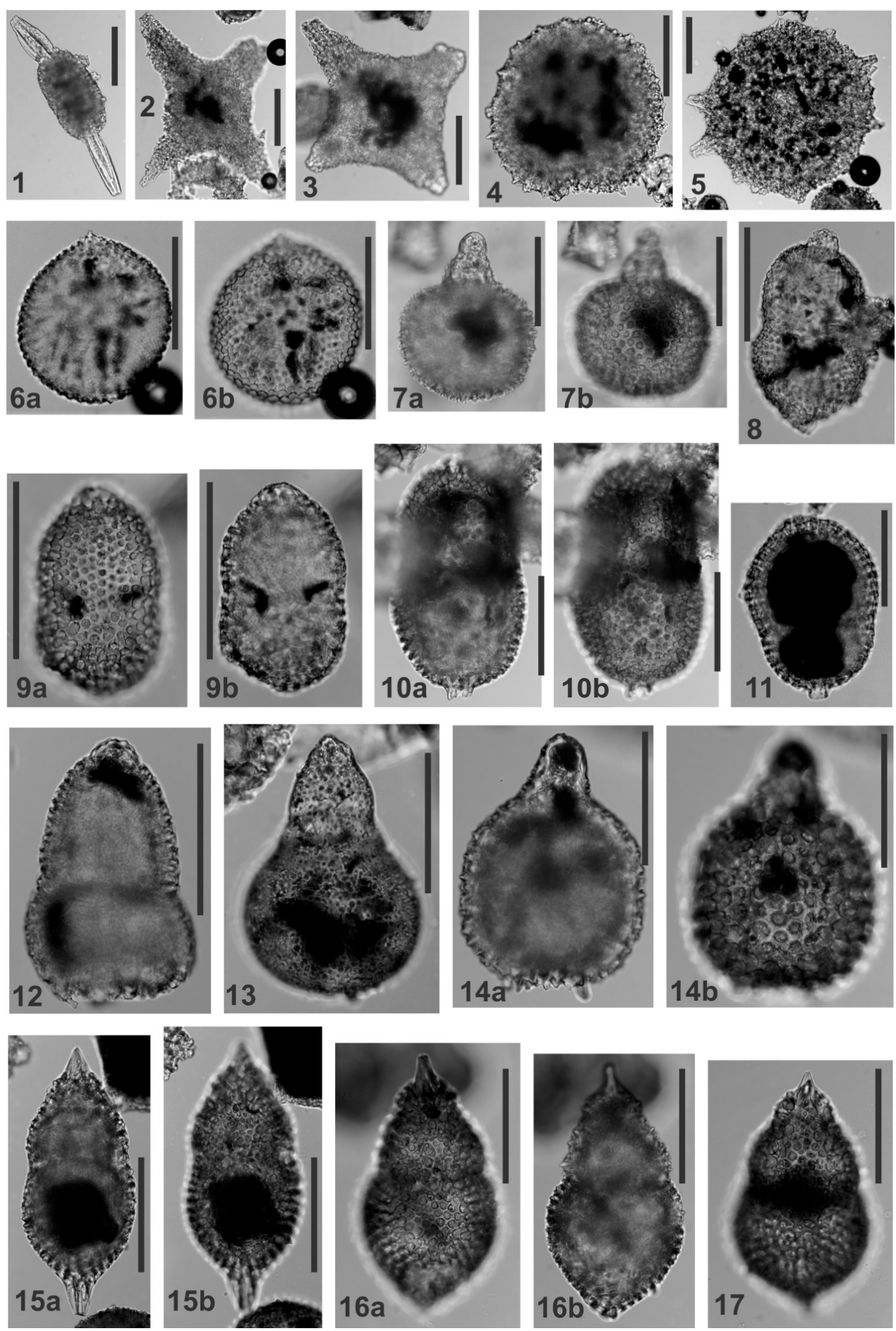
Plate P2. Selected radiolarians, Hole U1520C. Scale bars $=100 \mu \mathrm{m}$. Location of specimen on slide (A or B) is given by England Finder coordinates. 1a-8. Theocapsomma? cf. matsumotoi; 42R-4, 36-39 cm: (1a, 1b) A-J27/1, (2a, 2b) A-G31/4, (4a-4c) A-D40/0, (5a, 5b) A-D43/4, (6a, 6b) A-G37/4; 42R-3, 56-59 cm: (3) AG43/4; 43R-2, 114-118 cm: (7) A-V57/4, (8) A-P56/2. 9a-10b. Theocapsomma rara; (9a, 9b) A-K45/3 (43R-1, 128-131 cm), (10a, 10b) A-G39/0 (42R-3, 56-59 cm).
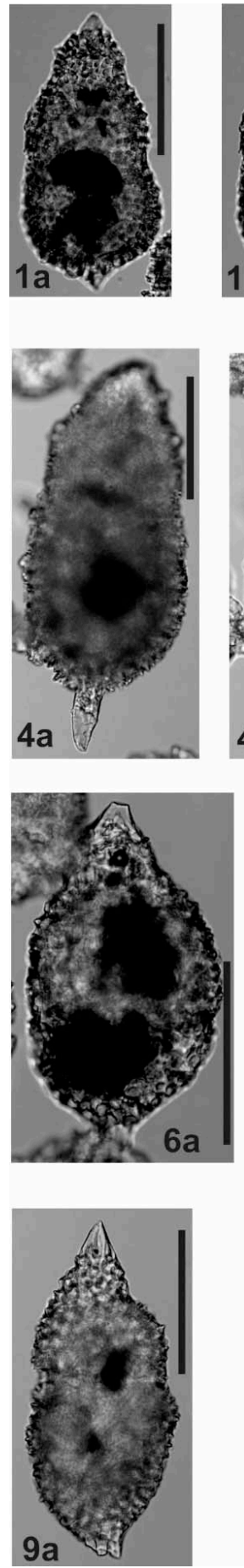
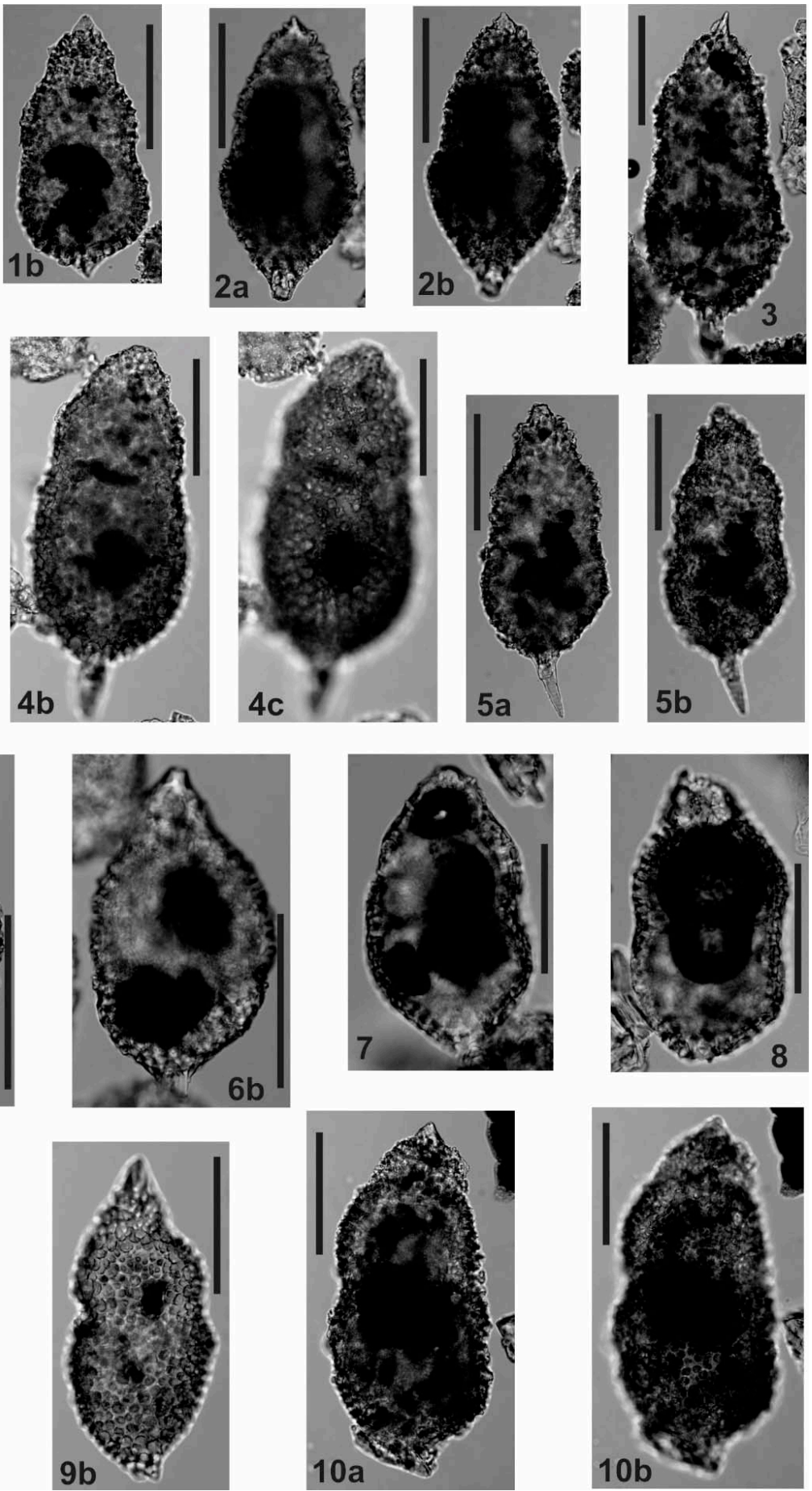
Plate P3. Selected radiolarians, Hole U1520C. Scale bars $=100 \mu \mathrm{m}$. Location of specimen on slide (A or B) is given by England Finder coordinates. 1a-3b. Obesacapsula somphedia; (1 a, 1b) A-T41/0 (42R-4, 36-39 cm), (2) A-E54/3 (42R-3, 56-59 cm), (3a, 3b) A-T37/0 (43R-1, 128-131 cm). 4, 5. Lithocampe manifesta (43R-2, 114-118 cm); (4) B-S34/2, (5) A-K56/2. 6-7b. Distylocapsa veneta; (6) A-E62/1 (42R-4, 36-39 cm), (7a, 7b) A-E61/0 (43R-1, 128-131 cm). 8a, 8b. Stichomitra communis (42R-3, 56-59 cm) (A-F51/2). 9a-10b. Stichomitra carnegiense (42R-4, 36-39 cm); (9a, 9b) A-U30/1, (10a, 10b) A-G34/3. 11. Xitus spinosus (42R-4, 36-39 cm) (A-D50/0). 12, 13. Amphipyndax stocki; (12) A-Q45/0 (43R-2, 114-118 cm), (13) A-E39/2 (42R-4, 36-39 cm).
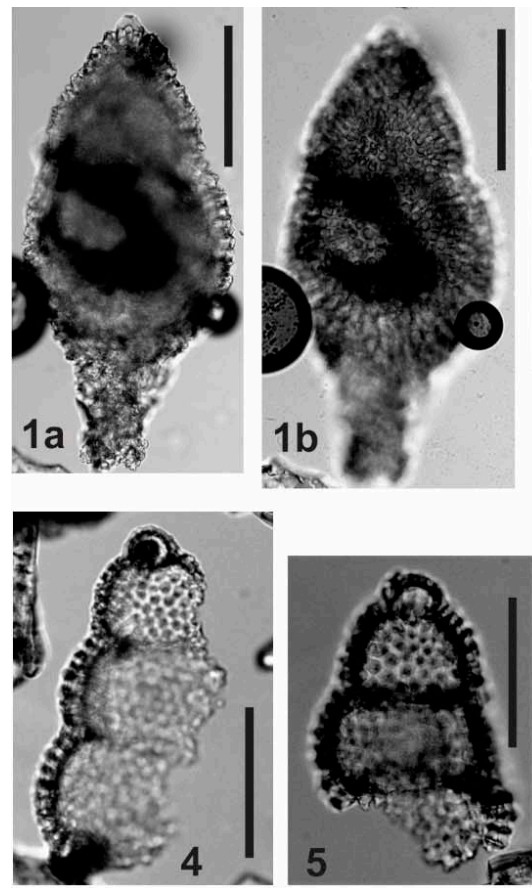

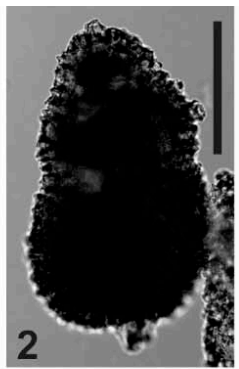

2

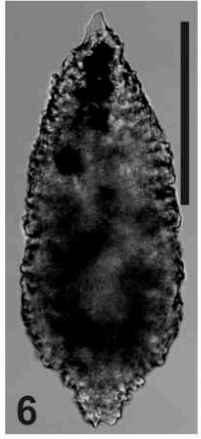

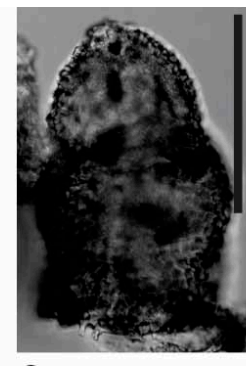

$3 a$

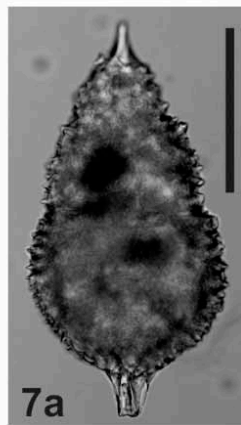

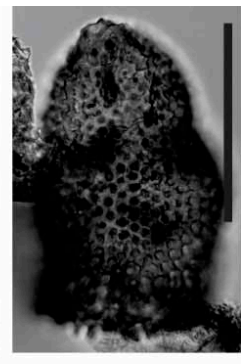

$3 b$

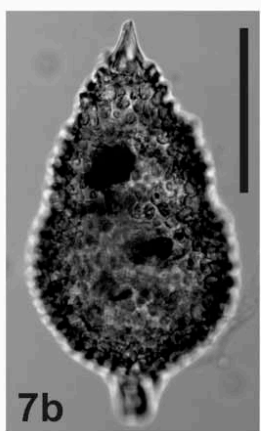

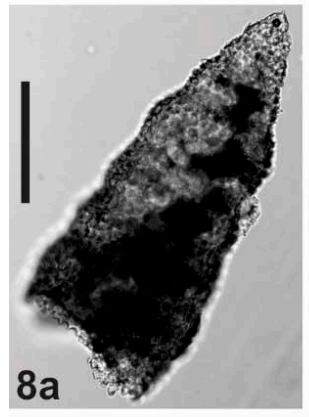
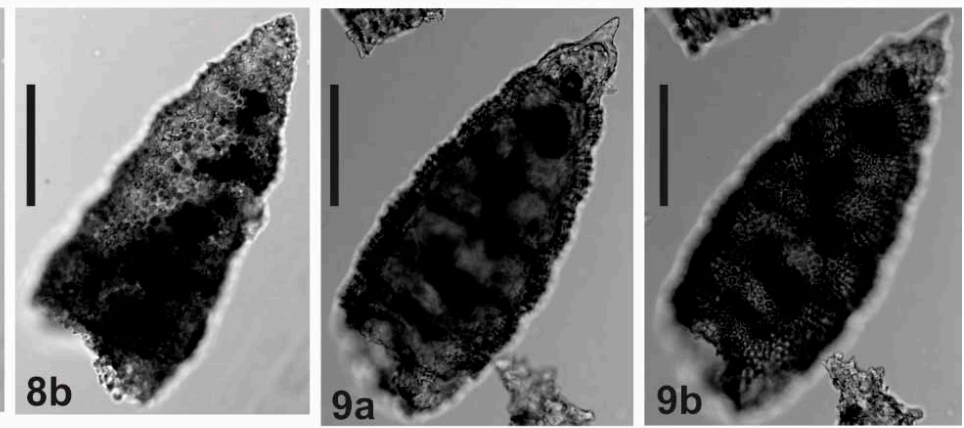

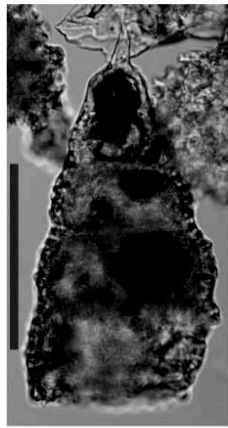

$10 a$

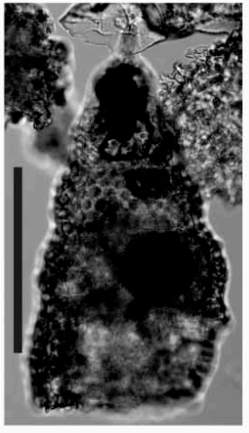

$10 b$
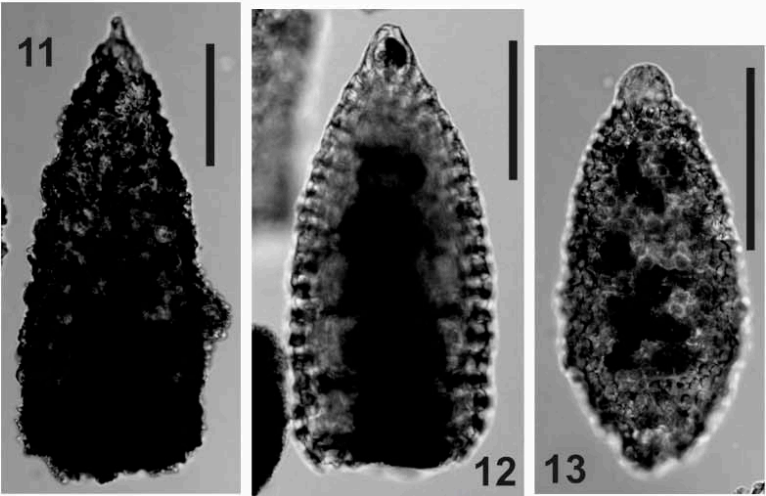
Plate P4. Selected radiolarians, Hole U1520C. Scale bars $=100 \mu \mathrm{m}$. Location of specimen on slide (A or B) is given by England Finder coordinates. 1a, $1 \mathrm{~b}$. Amphipyndax aff. stocki. (43R-1, 128-131 cm) (A-K42/1). 2. Dictyomitra multicostata (43R-1, 128-131 cm) (A-R53/0). 3. Dictyomitra urakawaensis (42R-4, 36-39 cm) (AG37/0). 4a-6. Archaeodictyomitra squinaboli; 42R-4, 36-39 cm: (4a, 4b) B-Q31/0, (5) A-U39/2; 43R-1, 128-131 cm: (6) A-G52/0. 7a, 7b. Mita gracilis (42R-4, 36-39 $\mathrm{cm})(\mathrm{A}-\mathrm{G} 33 / 0)$. 8. Mita gracilis? (43R-2, 114-118 cm) (A-X54/3). 9. Mita sp. (43R-2, 114-118 cm) (A-R32/1). 10. Lithomelissa cf. hoplites (42R-4, 36-39 cm) (A$H 32 / 1)$.
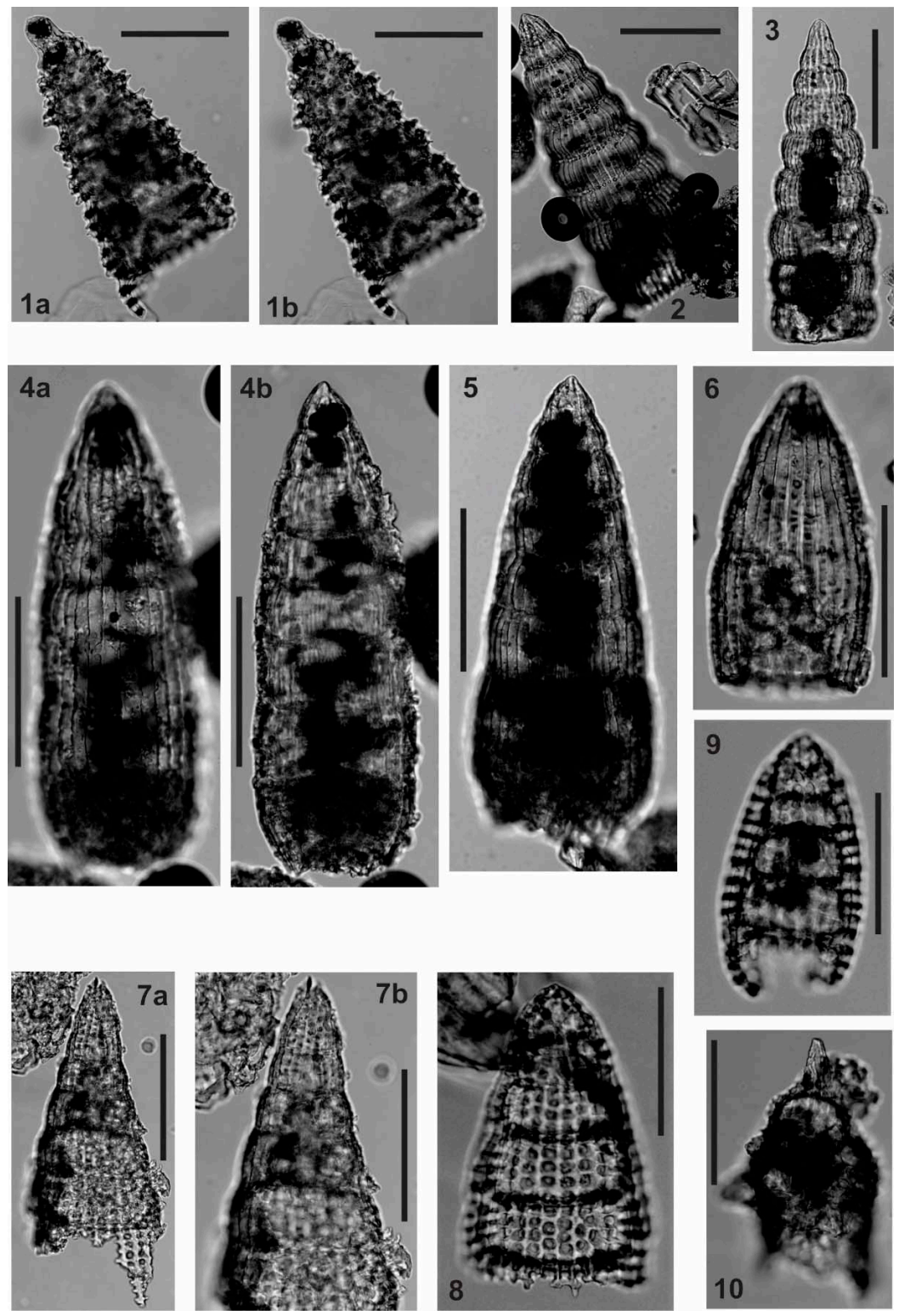